\title{
The Effect of Intellectual Capital and Capital Adequacy on Credit Risks and Financial Performance (A Study of Commercial Banks at the Indonesia Stock Exchange )
}

\author{
Ketoet Astawa \\ Student of Doctoral Program of Business Administration, Faculty of Administrative Science, \\ Brawijaya University, Jalan M.T. Haryono No. 163 Malang, East Java - Indonesia, Postal Code 65145 \\ Suhadak and Sri Mangesti Rahayu \\ Department of Business Administration, Faculty of Administrative Science, Brawijaya University, \\ Jalan M.T. Haryono No. 163 Malang, East Java - Indonesia, Postal Code 65145
}

\begin{abstract}
This study aims to examine and explain the effect of intellectual capital and capital adequacy on credit risk and financial performance. Effect of credit risk on financial performance. The study population was 43 with a sample of 31 Commercial Banks that had been listed on the Indonesia Stock Exchange. The observation period from 2012 to 2016. The sampling method was purposive sampling, data of 155 bank financial statements. The data analysis technique uses statistical procedures to test hypotheses with the Generalized Structured Component Analysis (GSCA) software. The finding of this study is that intellectual capital has a negative and significant effect on credit risk. Intellectual capital has a positive and significant effect on financial performance. Capital adequacy has a positive and significant effect on credit risk, and financial performance. Credit risk has a negative and significant effect on financial performance. This study suggests that managers of banks, especially bank go public, pay more attention to the variable intellectual capital in the sense that any additional investment in the 3 IC components (human capital, structural capital and capital employed) can be efficiently used to create value added and increase company value. IC is the only source of value creator in the future, which implicitly utilizes tangible and intangible assets and mitigates risk optimally. Recommendations for further research can expand the general banking sector population in longer research periods to get better results.
\end{abstract}

Keywords: Intelletual capital, capital adequacy, credit risk, financial performance

DOI: $10.7176 /$ RJFA/10-10-22

Publication date:May $31^{\text {st }} 2019$

\section{Introduction}

Commercial banks as business entities are always oriented towards maximizing profits to improve the welfare of owners and other stakeholders (including management, employees, customers, government and the general public). Company management must have the ability to manage intellectual capital as a source of value creation. Managing capital adequacy as a buffer against the risk of loss of the loan portfolio (NPL). Operational efficiency to increase profitability and sound financial performance. Mitigating credit risk to maintain profit growth stability.

Resources owned by the banking industry are classified according to their nature, consisting of tangible assets and intangible assets. Tangible banking industry resources include: cash, liquid cash equivalent assets and minimum statutory deposits held at Bank Indonesia, fixed assets, capital adequacy, earning assets. Intangible resources even though there is no unity of views in intellectual capital literature, but it has been agreed by researchers (Macerinskiene et al., 2013) that intangible assets are content of intellectual capital, or a collection of all non-physical assets available in the company (bank). These non-physical assets are in the form of human resources with all the knowledge, skills, positive motivation, experience and abilities, but also in the form of: technology, organizational operational systems, and good relations between the bank and customers, customers and other related parties.

Experts state that intellectual capital includes three elements, namely: human capital, structural capital, and capital employed, where the level of efficiency of use is measured by the Value Added Intellectual Coefficient (VAIC) model that was first developed by Pulic since (1998, 2004 and 2008). As the company's performance indicators, the higher VAIC indicates the higher efficiency of value creation in a financial or non-financial sector company. Conversely, VAIC is low, indicating the level of efficiency of value creation is decreasing, or value is destroyed.

The main role of the intellectual capital (IC) factor in the banking industry is "value creation" (value creation), and determining the degree of quality of financial services to bank customers in order to improve bank competitiveness (Goh, 2005). Intellectual capital is expected to provide an important contribution to the banking industry in the form of: increasing the creation of added value which will be reflected in the price to book value (PBV) of publicly listed banks. PBV ratio that is greater than 1 (one) is a benchmark for the success of intellectual 
capital (IC) creating value in the company, for example: Issuer shares in the Information Technology (IT) industry on the New York Stock Exchange (NYSE) for the past few decades (Chen et al., 2005).

The resource based view of the firm (Grant, 1996) is a structure theory and corporate behavior (a theory of firm structure and behavior) explains and predicts why some companies are able to have a sustainable competitive advantage to produce the highest income. A company is a unique bond of sources and internal capabilities with the main task of management is to utilize these internal resources to maximize the value of the company. Each bank must have quality tangible and intangible resources to be managed efficiently, so that the bank has a competitive advantage, is able to increase profits and corporate value.

Intellectual capital (IC) literature states that the success of value creation for companies by utilizing intangible assets as a source of sustainable competitive advantage through interaction between IC components themselves. The results of value creation in the company will appear in the ratio of market to book value or price to book value, which is a ratio that shows the difference between the book value per unit of stock in the balance sheet and market price at market closing at any given time. For example Berglund et al., (2002: 25) and Chen et al., (2005) state that in the era before the 1990s the ratio of MBV of companies in the USA was in the same position $(1: 1)$ and then in the era after the 1990s became more than 10 times $(1: 10)$ even specifically for IT companies achieving MBV (1 : 50). This fact shows that IC has contributed to the increase of the company's value more than 10 times, among others: Microsoft, Intel, Cocacola and other IT companies, based in the USA.

Meles et al., (2016: 6) explain that a very effective way to increase sustainable profitability in the banking industry is by increasing efficiency and efficiency in managing intellectual capital resources. Value relevance theory (Ohslon, 1995: 681-682), which was further developed by Veltri et al., (2011: 234) explains that market valuation of company shares can be done on the basis of fundamental accounting variables and relevant "other information". Accounting variables and other relevant information include: ordinary stock book value, and company income (book value of common stock and earnings), while the efficiency level of the utilization of intellectual capital (IC) in creating value with the VAIC model is categorized as information others are measured by monetary units (Pulic, 1998, and 2004).

Previous research has examined whether the fundamental accounting variables and "other information" in the form of intellectual capital variables have relevant values for market participants, and how the roles of each IC component (human capital, structural capital and capital employed) in creating value creation, has been carried out by Veltri et al., (2011) in the financial sector industry in the Italian stock exchange. Research findings confirm that there is a positive relationship between book value and earnings, and intellectual capital with firm value. The efficiency of human resource use (HCE) is more dominantly affecting the value of the company compared to the effect of the other two IC components, namely, capital structure efficiency (SCE) and efficiency of equity use (CEE).

The empirical findings of the next researchers state that there is a significant effect between intellectual capital on firm value and financial performance (market value and its financial performance). This empirical finding is the result of research conducted by Asadi (2013), and Japari (2013) on the Tehran exchange. Sudaryono et al. (2012) on the Indonesia Stock Exchange, Samuel et al., (2011) on the Hong Kong stock exchange. Other empirical findings show that there is no significant effect between intellectual capital (IC) and financial performance and firm value carried out by $\mathrm{Yu}$ et al., (2010) on the Hong Kong stock exchange for companies belonging to the Hangseng Index, stating that there is no empirical effect between VAIC for four financial indicators (MBV, ATO, ROA, ROE) but the VAIC component can predict substantive variations in business performance.

The findings of Amir et al., (2011) on the Tehran exchange state that it has failed to support previous findings on the effect of SCE on financial performance (ROA, ROE) unless there is an acknowledgment that IC is a strategic asset that is important for sustainable competitiveness. The results of previous studies regarding the effect of intellectual capital or ICE (HCE and SCE) on credit risk have not been found in the IC literature in Indonesia, but refer to the findings of Ghosh and Maji (2014) in his study of Indian banking revealed that ICE had a negative effect on risk credit.

The banking industry with the main business carrying out the intermediation function between groups that have surplus funds and groups that need funds, are always faced with credit risk. Credit risk comes from: customers who obtain credit and non-credit facilities that experience default, and the risk of loss of impairment on bank investments in other earnings assets (Maurin and Toivanen, 2012: 2). The study of banking financial performance that is associated with risk factors is very important because risk factors affect the bank's profitability in the long run (Amir et al., 2011).

Capital buffer theory (Marcus, 1984) explains that excess capital above the minimum level of needs is intended as a "buffer" of risk and to reduce the likelihood of future financial difficulties (Heid, 2004) and Deelchan et al., (2009). Banks need a minimum capital adequacy position based on Central Bank regulations that refer to the Basel I (1988) package, aimed at ensuring bank compliance with the minimum capital adequacy provisions that apply internationally in order to create banking system stability globally. Banks need to anticipate credit risk factors, and banks maintain high performance, to avoid failure in the event of a systemic economic and financial 
crisis. The consequence is that credit portfolio risk and capital adequacy are hypothesized to have a positive direction, so that the bank will increase its capital adequacy ratio when credit risk and other earning assets risk increase.

Researchers who explore the findings of the effect of capital adequacy on credit risk, still seem to have ambiguous doubts about these findings as follows; (1) Higher risks can increase the likelihood of defaults that encourage banks to increase capital adequacy. (2) Systematic risk that is increasingly high can result in decreased financial performance and the potential to reduce the capital adequacy of the banking industry.

Capital buffer can be used as a basis to ensure that the banking industry business can maintain its capital adequacy level in excess of the minimum capital ratio requirement of $8 \%$ CAR (Jokipii and Milne, 2009). Previous research related to the effect of capital adequacy on risk exposure in Australian banks showed a positive effect in the sense that any capital increase was intended to anticipate an increase in bank business risk (Gizycki, 1999). The positive relationship between capital adequacy and credit risk is found in Swiss banks (Bichsel and Blum, 2002) stating that the higher the capital adequacy, the higher the level of credit risk faced. Amidu et al., (2006) found that in Ghana banking, Altumbas et al., (2007), Murin and Toivanen (2012) found banks in the European Union, with explanations that banks with high credit risk tended to have large equity, low liquidity and profitability is also low.

Other empirical findings appear inconsistent with the results of previous studies, namely there is a negative relationship between capital adequacy and credit risk (Deelchand, 2009) at Cooperative banks in Japan, Kochubey and Koalczyk (2014) in commercial banking in the US, and (Aymen, 2015) in banking Tunis. Athanasouglou (2011) states that state banks in the South Eastern Europe region state that the effect of capital adequacy and credit risk is negative or positive and its significance depends on the level of capital adequacy owned (lower or higher than the minimum capital provisions).

Capital adequacy is also an important key for the success of the banking industry in developing its business (intermediation), because with sufficient capital (CAR of more than $8 \%$ ) will be able to expand in proportion to the increase in capital above the minimum requirement. Minimum capital adequacy refers to the provisions of the Bank for International Satel known as Basel I (1988), and has been outlined in the last Bank Indonesia regulation No.15 / 12 / PBI / 2013, article 2 paragraph 3a - 3d, that is, with a minimum CAR 8\% of risk-weighted assets. A minimum capital adequacy ratio of $8 \%$ can be inteIDRreted as an increase of IDR.1, - on the equity side, the bank can expand accumulative credit in the amount of IDR.12,50. The bank can have a position of weighted assets according to the maximum risk of IDR.12,50 if there is a minimum equity or core capital of IDR. creating value efficiently, it is certain that it will encourage higher financial performance.

The effect of capital adequacy on financial performance reveals the existence of positive and significant effects (Berger et al., 2002, Amidu et al., 2006, Gohar et al., 2011, Skopljak et al., 2012, and Epure et al., 2013). Positive effect also occurs between capital adequacy on credit risk (Amidu et al., 2006, Altumbas et al., 2007, Gohar et al., 2011, Mbarek et al., 2011, Athanasouglou, 2011, and Abbazadeh et al., 2013).

Trade off theory (Modigliani and Miller, 1963) states that leverage has a positive relationship with profitability, because tax deductable on interest on debt and reducing the cost of capital can improve financial performance and benefit shareholders, with the exception of bankruptcy costs, financial difficulties. This trade off theory (Modigliani and Miller, 1963) is closer to the concept of capital structure which recognizes the relationship between firm value and the use of debt funds (leverage) to a certain level (Berger et al., 1995: 4, Naidu, 2011: 1112) . Does this theory apply to the banking industry? Berger et al. (1995) responded by stating that market-based capital structure with an indicator of equity to total assets ratio (EAR) can maximize the value of the company with a note, still associated with assumptions on trade-off theory (Modigliani and Miller, 1963), and is equipped with components of intermediation transaction costs, asymmetric information problems, and government guarantees on the security of deposit funds. The bank can maximize the use of debt to increase profit and company value, which is reflected in the increase in its share price.

Credit risk has a negative effect on bank financial performance and the development of its stock prices, this is revealed from the results of research: Amidu (2006), Mbarek et al. (2011), Gohar et al. (2011), Epure et al. (2013), Mendoza and Rivera (2017). Credit risk control is an important factor that must be considered so that the goal of maximizing profits can be achieved with the lowest possible risk (Deelchan et al., 2009, Epure et al., 2013, and Alshatti, 2015) respectively at Cooperatives banks in Japan, Bank Costarika, and banks in Pakistan.

Effect between variables in the context of the management of the banking industry, which starts from the variable intellectual capital that focuses on creating value through competitive products and financial services. Then anticipation of credit risk and the risk of investment funds in other producing assets, the availability of capital that exceeds the minimum level of need ( $8 \% \mathrm{CAR})$, and the achievement of maximum operational efficiency level (score 0 - 1). Variable intellectual capital, Capital Adequacy, credit risk and financial performance need attention in the implementation of an effective and productive banking intermediation function. Effective and productive implementation of intermediation is expected to generate maximum and sustainable financial performance (profitability). Maximum financial performance can be achieved at a relatively low level of credit risk, will be a 
positive signal for market participants (investors) to invest in shares of the banking sector.

The company seeks to maintain financial performance above the industry average, this can certainly increase the value of the company. High corporate value is reflected in the stock price with the category "premium" meaning that certain stock prices that occur in the market are higher than the fair price, and are the opposite of the discount price, meaning that the market price of certain shares is below its fair price.

Based on the description of theoretical perspectives and empirical findings of previous researchers regarding the effect of intellectual capital, capital adequacy, credit risk, on financial performance in the banking industry, it appears inconsistent among the findings of previous researchers. The findings of the effect between the intended variables, some states there are positive effects, other findings state there are negative effects, there are significant effects and there is no significant effect. This study aims to re-examine empirically the effect of variables on previous findings in this research model, to obtain empirical evidence whether the results of this study support or not support the theoretical basis and previous research models with relevant research. The originality of this research is (1) Reconstructing various previous research models (financial and banking sectors) into a new research model, and completing the "research gap" that existed in previous studies. (2) Test empirically the effect of intellectual capital, capital adequacy, credit risk, on financial performance in the banking industry in Indonesia.

\subsection{Research Problems}

1) Does intellectual capital have an effect on credit risk?

2) Does intellectual capital have an effect on financial performance?

3) Does capital adequacy have an effect on credit risk?

4) Does capital adequacy have an effect on financial performance?

5) Does credit risk have an effect on financial performance?

\subsection{Research Objectives}

1) Test and explain the effect of intellectual capital on credit risk.

2) Test and explain the effect of intellectual capital on financial performance.

3) Test and explain the effect of capital adequacy on credit risk.

4) Test and explain the effect of capital adequacy on financial performance.

5) Test and explain the effect of credit risk on financial performance.

\section{Literature Review}

\subsection{The Effect of Intellectual Capital Against Credit Risk}

Ghosh and Maji's research (2014) aims to examine the impact of Intellectual Capital Efficiency (ICE) and its components. Human Capital Efficiency (HCE) and Structural Capital Efficiency (SCE) on credit risk and insolvency of Indian commercial banks during the period 1998 to 2012. Using panel data analysis techniques found that intellectual capital has a negative correlation with credit risk. Human Capital Efficiency (HCE) has a significant negative correlation with credit risk, meaning that the use of human capital is efficient and effective or in other words the ability of resources to manage credit risk will reduce the level of credit risk (bad credit). Greater effect of ICE and HCE on credit risk from public sector banks than private sector banks, also proved that large banks are more efficient in using intellectual capital in managing credit risk, while small banks depend on capital adequacy ratios. The effect of intellectual capital on the risk of bank insolvency, current efforts fail to reach definite conclusions (Ghosh and Maji, 2014).

Credit risk is all risks associated with core banking loan activities to customers (Ghosh and Maji, 2014). After the collapse of two large international banks (Franklin National Bank in Long Island in the USA and Bankhaus Herstatt in Germany in 1974), the Basel Committee on Banking Supervision designed a framework for capital adequacy in 1988, known as Basel I, to establish a minimum capital level for internationally active banks with the aim of promoting the health and stability of the international banking system and increasing competitive equality among international banks (Stephanou and Mendaza, 2005; and Jablecki, 2009) Voluntary implementation of the Basel I framework by a large number of countries has made it a globally accepted standard and gradually the Capital Adequacy Ratio (CAR) has emerged as an important benchmark for assessing financial strength and bank health.

The Basel Committee recommends a minimum (8\%) of capital for risk-weighted asset ratios, which primarily focus on credit risk. Increasing competition and rapid changes in the operating environment under the effect of deregulation, technological advances and innovations in financial products and services in the past, the banking sector around the world has witnessed changes in the business environment and banks are forced to face various types of risks besides credit risk. Measurement and management of other risks, such as liquidity, and significant market and operational risks in this changing scenario. All risks are interrelated, and if management fails in credit management, it will invite other risks which can eventually lead to a higher probability of bankruptcy.

During the financial crisis, it should focus on the importance of managing all risks and integrated efficiency 
to reduce the possibility of bankruptcy as a result of the risk of bank insolvency, because the business environment is always changing. The Basel I agreement has been criticized by many researchers (Mingo, 2000; and Stephanou and Mendoza, 2005). The main focus is on credit risk, the use of arbitrary risk categories and arbitrary weights that have nothing to do with default risk and inappropriate methodologies for assessing risk. In response to the banking crisis of the 1990s and to overcome the main limitations of Basel I, the Basel Committee has proposed in 1999 a more comprehensive capital adequacy agreement, known as Basel II, which recognizes market risk and operational risk along with risk credit in the hope of promoting stronger risk management practices by the banking industry.

Furthermore, the committee has issued Basel III guidelines in December 2010 to promote a more flexible banking system that focuses on four important banking parameters for capital, leverage, funding and liquidity. An adequate reason to preserve capital is that this is an indicator of sufficient bank financial resources to provide adequate protection against unexpected losses and a decline in the value of assets. Adequate banking capital provides a cushion for failure. If the bank's loss exceeds bank capital, then the bank's capital becomes bankrupt, and the higher the bank's capital, the higher the bank's solvency. The theoretical implication of this empirical is that an increase in intellectual capital will reduce credit risk. Based on the explanation of the concept of intellectual capital and previous empirical studies that intellectual capital has an effect on credit risk, the research hypothesis is formulated as follows:

Hypothesis 1: Intellectual capital has an effect on credit risk.

\subsection{The Effect of Intellectual Capital on Financial Performance}

Intellectual Capital can be interpreted as intangible assets that are not explicitly listed on the company's balance sheet but have a positive impact on performance and success (Brooking, 1996; Kayacan and Alkan, 2005; Mondal and Ghosh, 2012; Ozkan et al., 2017). There is no consensus in the literature about the definition of intellectual capital, however, researchers also agree on the Intellectual Capital component. Researchers widely recognize that intellectual capital includes three components, namely human capital, structural capital and customers capital (relationship). Human capital can be defined as knowledge that leaves the organization when people leave and includes the skills, abilities, experience and expertise of employees. Structural capital includes systems, structures and organizational processes and involves non-physical components such as data bases, organizational charts, management processes and business strategies. Customers capital refers to all intangible assets that regulate and manage the relationship of an organization, which consists of organizational relationships with customers, suppliers, shareholders and other stakeholders (Joshi et al., 2013; Kurt, 2008; Mondal and Ghosh, 2012).

After realizing that intellectual capital has an impact on value creation and improving company performance, various methods have been developed to measure it. The method used to measure values created by intellectual capital, including market-to-book ratios, Tobin's Q ratio, calculates intangible values (Steward, 1997), balanced scorecard (Kaplan and Norton, 1996), Skandia IC Navigator (Edvinsson, 1997), "IC-index" intellectual capital services (Roos et al., 1997), IC technology broker audits (Brooking, 1996), monitor intangible assets (Sveiby, 1997), economic value added (Steward, 1991), value added market, and value added the coefficient of value added intellectual capital (VAIC) model (Celikkol, 2008; Karacan and Ergin, 2011; Pulic, 1998, 2004, 2008; Yalama and Coskun, 2007).

The VAIC model developed by Pulic $(1998,2004)$ which measures the performance of a company's intellectual capital. The VAIC model expresses the intellectual ability of the organization and whether its sources are used efficiently or not. VAIC measures added value created per monetary unit invested in each source. The higher the VAIC of an organization, the higher the added value created by organizational resources (Pulic, 2004).

Previous research has shown that intellectual capital has a positive effect on financial performance as measured by company profitability: return on assets, and return on equity, earnings per share. The results of Poraghajan's study (2013) used company data in the Tehran stock market, that all variables of intellectual capital were positively correlated with ROA. The results of the research by Deep and Narwal (2014) Nuryaman (2015) show that only capital value added is used (VACA) which significantly affects the profitability of the company. The theoretical implication of this empirical is that increasing intellectual capital will improve financial performance. Based on the explanation of the concept of intellectual capital and previous empirical studies that intellectual capital has an effect on financial performance, the research hypothesis is formulated as follows:

Hypothesis 2: Intellectual capital has an effect on financial performance.

\subsection{The Effect of Capital Adequacy on Credit Risk}

The capital adequacy ratio is a measure of a bank's financial strength expressed by the ratio of capital (net worth and subordinated debt) to a weighted credit risk exposure in the form of a loan (Economic Times Bureau, 2010 in Edvinsson, 1997). The capital adequacy ratio is calculated by dividing the shareholders' total equity by total assets. A high capital adequacy ratio shows that the owner of the bank has a larger share of ownership than the creditor in the bank's assets. Credit risk is obtained by dividing loan loss reserves with the total loan portfolio. A high credit 
risk index indicates that banks have a higher level of problematic loans (Mendoza and Rivera, 2017).

This research is based on "Bearing Risk Theory" developed by Hawley (1900), explaining that an important function of an entrepreneur is taking risks, a function that cannot be delegated to others. Hawley argues that profit is a gift for risk takers. This theory further states that some risks are inherent in every speculative business enterprise in the business view. So, in the banking business, management must bear the risk of earning profits in return for risk taking. As Hawley (1900) states that risk levels vary in different businesses, but there is a positive relationship between risk and profit.

Hypothesis 3: Capital Adequacy has an effect on credit risk.

\subsection{The Effect of Capital Adequacy on Financial Performance}

The capital adequacy ratio is a measure of the bank's financial strength expressed by the ratio of capital (net worth and subordinated debt) to risk weighted credit exposure in the form of loans (Economic Times Bureau, 2010 in in Edvinsson, 1997). This is also known as the risk-weighted asset capital ratio and is used to protect depositors and promote financial system stability and efficiency. The rationale for institutionalizing a standard capital adequacy ratio is what banks need to hold the minimum level of shareholder equity depending on the number of loans and risky loans. The Basel Committee on Banking Supervision (2015) has expanded the composition of capital adequacy for many years. Two types of capital are measured: (1) Tier one capital, which can absorb bank losses without stopping trade, and (2) Tier two capital, which can absorb losses in terms of closure and provide protection for depositors. Iloska (2014) shows that the strength and quality of capital effect s bank profitability. Low selfcapital ratios reflect high leverage and risk leading to higher borrowing costs.

Flamini et al., (2009) explained that capital adequacy is an important variable in determining the profitability of banks and large capital banks can signal to the market that the performance is better than the expected average. Banks that have large capital are less risky and produce lower profits because they are considered safer, so it can happen, a negative relationship between capital adequacy and profit. Naceur (2003) predicts a higher ratio of equity to assets to produce lower external funding needs and therefore higher profitability which shows higher financial performance. Overall, large capital banks are believed to reduce funding costs and reduce the possibility of bankruptcy.

Profitability is the ability of a business entity to generate profits from business activities carried out. This profitability shows financial performance which is an important element of bank value creation and an important step towards maximizing shareholder wealth. Previous research has used ROA, calculated by dividing net income with total bank assets, as the main measure of bank profitability that shows financial performance (Abbas et al., 2014; Akhtar et al., 2011; Ali et al., 2011; Aremu et al., 2013; Erina and Lace, 2013). ROE as a measure of financial performance profitability has also been used by Abbas et al. (2014); Gizaw et al., (2015). Size of net interest margin as a measure of profitability that shows financial performance used by Naceur (2003) and Aremu et al., (2013).

Staikouras and Wood (2004) used OLS and fixed effect regression models in investigating 685 banks in 13 European economies and found that the capital adequacy ratio measured by the ratio of equity to total assets showed consistently a capital adequacy ratio that had a significant effect on profitability. This means that banks that have a greater level of equity are relatively more profitable. Vong and Chan (2009) found that capital ratios had a significant impact on ROA, when they used panel regression at five commercial banks in Macao SAR. They concluded that capital structure is very important in influencing bank profitability. Akhtar et al., (2011) also concluded that in six Islamic banks in Pakistan, capital adequacy had a significant positive effect on ROA and ROE. Scott and Arias (2011) who found that the ratio of capital to total assets has a positive relationship with ROE in five US banks. Obamuyi (2013) used a fixed effect regression model to analyze data from 20 banks in Nigeria found that capital adequacy had a significant positive impact on ROA.

Roman and Danuletiu (2013) used multiple linear regression to examine 15 commercial banks in Romania, finding that capital adequacy had a significant positive relationship with profitability. Mendoza and Rivera (2017) examine the effect of capital adequacy on profitability from 567 rural banks in the Philippines. Using the ArellanoBond estimator method, found that capital adequacy did not have a significant impact on the profitability of rural banks in the Philippines. It is important for banks to examine more deeply if the injection of equity capital will result in higher profitability than the increase in debt. Rural banks need to improve internal control measures to ensure strict internal process implementation in lending operations (Mendoza and Rivera, 2017). The only study with unique results was from Poudel (2012) who found that the capital adequacy ratio had a negative relationship with profitability in 31 Nepalese banks.

Realizing the importance of profitability is effect $\mathrm{d}$ by the bank's capital adequacy ratio. The capital adequacy ratio is calculated by dividing the shareholders' total equity by total assets. A high capital adequacy ratio shows that the owner of the bank has a larger share of ownership than the creditor in the bank's assets. Profitability is measured in two aspects: ROA (net income / total assets) and ROE (net income / total equity). Capital adequacy as a cause of profitability (ROA and ROE). 
Capital Adequacy Ratio (CAR) is a ratio used to measure capital adequacy that supports bank assets that can have risks such as loans (Prastiyaningtyas, 2010). The formula for calculating CAR is capital divided by riskweighted assets. According to regulation No. 15/12 / PBI / 2013 from Bank Indonesia, banks are required to provide a minimum capital of $8 \%$ of risk-weighted assets (RWA). The increase in the CAR ratio means that the amount of capital increases and this indicates that banks can survive even if they suffer losses. This can increase the level of trust of customers and investors to deposit money. Such increases in bank deposits can function as funds to be given as bank loans and thus contribute to increasing the ability of banks to generate profits using their assets and thus ROA will also increase.

Bank profitability is the ability of banks to generate profits (Kasmir, 2014) and bank profitability can be measured by Return On Assets (ROA) which measures the ability of banks to generate profits with total assets (Sudiyanto, 2010). Regulation No. 13/24 / DPNP dated October 2, 2011, from Bank Indonesia stating that the minimum return on bank assets is $1.5 \%$. The higher the profit generated, the higher the ratio of Return On Assets. This means that the company is effective in using its assets to generate profits. The theoretical implication of this empirical is that capital adequacy will improve financial performance. Based on the explanation of the concept of capital adequacy and previous empirical studies that capital adequacy has an effect on financial performance, the research hypothesis is formulated as follows:

Hypothesis 4: Capital Adequacy has an effect on financial performance.

\subsection{The Effect of Credit Risk on Financial Performance}

Risk is the position of return on investment which is actually different from what is expected to return (Alshatti, 2015). Risk means the possibility of losing the original investment and the amount of interest accumulated in it. Credit risk is the risk that the borrower fails and does not respect his obligation to pay the debt. Can occur when partners cannot pay or cannot pay on time (Gestel and Baesens, 2008: 24). Credit risk is the possibility of losses due to the failure of the debtor to repay all types of debt, including loss of principal and interest, disruption of cash flow, and increased costs to be incurred in collecting receivables (bis.org).

Credit risk management practices to reduce losses caused by debtors failing to pay off the type of debt to creditors. Effective credit risk management cannot be separated from the development of banking technology, which will enable to increase speed in making decisions and at the same time reduce costs and control credit risk, this requires complete information from partners and contractors (Lapteva, 2009). Credit risk is one of the significant bank risks that are effect $\mathrm{d}$ by the nature of bank activities. The effectiveness of credit risk management not only supports the feasibility and profitability of the bank's business, but also contributes to systemic stability and for efficient allocation of capital in the economy (Psillaki et al., 2015). "Failure from a small number of customers might result in a huge loss for the bank" (Gestel and Baesems, 2008: 24), as has been identified by the Basel Committee as the main source of risk in the early stages considering the risks that will be faced by banks.

Bearing Risk Theory "developed by Hawley (1900) explains that an important function of an entrepreneur is taking risks, a function that cannot be delegated to others. Hawley argues that profit is a gift for risk takers. This theory further states that some risks are inherent in every speculative business enteIDRrise in the business view. So, in the banking business, management must bear the risk of earning profits in return for risk taking. As Hawley (1900) states that risk levels vary in different businesses, but there is a positive relationship between risk and profit.

Empirically there is a lot of research on the effect of credit risk management on financial performance, and how effective credit risk management can help reduce opportunities for failure and limit uncertainty in achieving the required financial performance. Most studies support the idea that there is a positive relationship between effective credit risk management and bank profitability, and some of these studies support the idea that there is a negative relationship between effective credit risk management and bank profitability. Hosna et al., (2009) found that the non-performing loan indicator carried out profitability as measured by (ROE) more than the capital adequacy ratio, and the effect of credit risk management on profitability was not the same for all banks.

Njanike (2009) found that the ineffectiveness of credit risk management led to a banking crisis, and inadequate risk management systems caused a financial crisis. Kithinji (2010) found that the larger part of bank profits is effect by variables other than credit and bad credit. Aduda and Gitonga (2011) found that credit risk management has an effect on profitability at a reasonable level.

Aruwa and Musa (2012) investigated the effects of credit risk, and other risk components on bank financial performance, found a strong relationship between the risk component and bank financial performance. Boahene et al., (2012) examined the relationship between credit risk and bank profitability, finding a positive relationship between credit risk and bank profitability. Gakure et al., (2012) investigated the effect of unsecured credit risk management techniques on bank performance. The conclusion that financial risk in a banking organization can result in a burden on the ability of the bank to fulfill its business objectives. Poudel (2012) explores various credit risk management indicators that affect bank financial performance, and finds that most bank financial performance indicators are effect by the level of risk (default). Musyoki and Kadubo (2012) tried to assess various parameters relating to credit risk management that affect bank financial performance, and found credit risk had an impact on 
bank financial performance; but the level of risk is the strongest predictor of influencing bank financial performance.

Nawaz and Munir (2012) found that credit risk management had an effect on bank profitability, and recommended that management should be careful in regulating credit policies that might not negatively affect profitability. Abdelrahim (2013) concluded that liquidity and bank size greatly effect $\mathrm{d}$ the effectiveness of credit risk management. Adeusi et al., (2013) concluded that risk management indicators (doubtful loans, and ratio of capital assets) had an effect on bank performance.

Berrios (2013) shows that unwise loans have a negative effect on net interest margins. Kaaya and Pastory (2013) show that credit risk indicators have a negative impact on bank performance. Ogboi and Unuafe (2013) concluded that bank financial performance is effect $\mathrm{d}$ by credit risk management and capital adequacy. Abiola and Olausi (2014) reveal that bank profitability is effect d by credit risk management. Singh (2013) revealed that effective risk management is very important for any bank to achieve financial health. Kurawa and Garba (2014) reveal that the credit risk management variable has an effect on bank profitability.

Hantono (2017) found that the indicator of Non-performing Loans (NPL) had a positive impact on bank profitability as measured by return on equity (ROE) and return on assets (ROA). Christaria and Kurnia (2016) state that Non-Performing Loans (NPL) is the level of bank bad debts. The smaller the NPL ratio, the wiser the bank is in giving credit to customers and this is with the aim of achieving the right target. This practice makes customers and investors believe that the money deposited in the bank will be properly managed thus increasing the bank's ability to generate profits using its assets. This means that the bank's profitability, the proxy for ROA, will also increase. According to Regulation No. 15/2 / PBI / 2013 from Bank Indonesia, the ratio of non-performing loans (Non-Performing Loans) should not exceed $5 \%$ of total credit (Haneef et al., 2012). Christaria and Kurnia (2016) found that credit risk (Non Performing Loans) had a non-significant effect on the financial performance (ROA) of commercial banks in Indonesia.

Alshatti (2015) revealed that credit risk management has a significant effect on the financial performance (ROA and ROE) of Jordanian commercial banks, then concluded that credit risk management indicators (gross credit / gross loans, provision for net loss / facility facilities and leverage ratios) have an effect significant financial performance of Jordanian commercial banks. Banks must establish adequate credit risk management policies by implementing stringent credit estimates beforehand, lending to customers, and banks designing an effective credit risk management system. Banks must establish an appropriate credit risk environment; the bank operates under a healthy loan process; maintain credit in accordance with administration that involves monitoring; sufficient processing and control over credit risk, and banks need to put in place and develop a strategy that will not only limit bank exposures to credit risk, but will develop bank performance and competitiveness (Alshatti, 2015). Mendoza and Rivera (2017) also show that it is very important for banks to understand which risk factors have a greater impact on financial performance and use better risk-adjusted performance measures to support the strategy. Rural banks must establish credit risk management in establishing processes ranging from initiation to credit approval, taking into account the practice of sound credit risk management. The theoretical implication of this empirical is that credit risk will reduce financial performance. Based on the explanation of the concept of credit risk and previous empirical studies that credit risk has an effect on financial performance, the research hypothesis is formulated as follows:

Hypothesis 5: Credit risk has an effect on financial performance.

The conceptual framework of this research was developed based on Intellectual Capital Theory (Pulic, 1998), capital structure theory within the framework of corporate risk management aims to increase profitability, optimal capital structure, and improve bank financial performance. Bearing Risk Theory "developed by Hawley (1900) explains that an important function of an entrepreneur is taking risks, a function that cannot be delegated to others. Intellectual capital and capital adequacy will reduce credit risk and increase financial performance. This study will examine the effect of intellectual capital, and capital adequacy on credit risk and bank financial performance within the framework of intellectual capital theory, capital structure theory, risk management, which can direct corporate management to make managerial decisions that minimize credit risk and improve financial performance, so that welfare shareholders can be achieved. The conceptual framework of this research is as shown in Figure 1, as follows: 


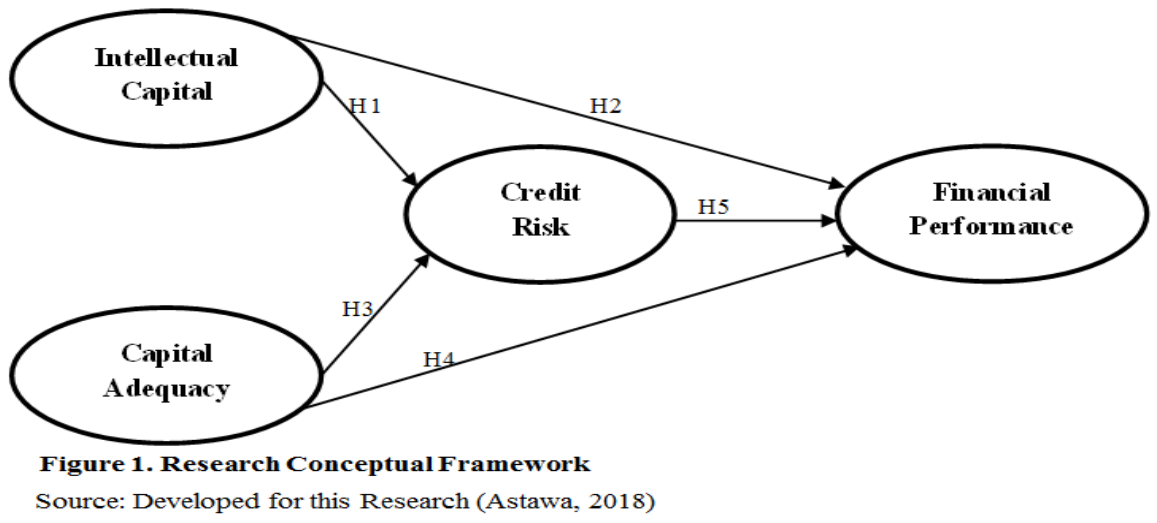

\section{Research Methods}

\subsection{Types of Research}

This type of research is explanatory research, namely research that explains the effect between variables, using secondary data. This research, aimed at explaining the effect between variables analyzed, and drawing conclusions that are useful for the development of science and used as a method of solving actual problems that occur in the field. This study focuses on empirical testing of the theory through testing the effect between variables and measurements and analysis techniques using statistical procedures to test hypotheses. The paradigm of this research is the positivistic paradigm, where conclusions from the results of research on the sample are seen to be generally applicable to the entire study population.

\subsection{Research Variables and Operational Definitions}

This study consisted of six variables namely Intellectual Capital, Capital Structure, credit risk and Financial Performance.

\subsubsection{Intellectual Capital Variables (X1)}

Intellectual capital is a company resource in the form of components of intangible assets that have the potential to create "added value" to the company's performance and business success as a whole, although explicitly it is not seen in the company's balance sheet. Referring to the study of Pulic (2004, 2008), and Asadi (2013). The Intellectual Capital variable, known as the value-added intellectual coeifficient (VAIC) model, is measured by three indicators: Capital Employed Efficiency (CEE), Human Capital Efficiency (HCE) and Structural Capital Efficiency (SCE). Capital Employed Efficiency (CEE) is calculated by the following formula:

Capital Employed Efficiency $(\mathrm{CEE})=\frac{\text { Value added }}{C E}$

Where CEE is capital employed efficiency coefficient, = Value Added, divided by CE or book value from the company's net assets.

Human Capital Efficiency (HCE). Human capital (HC) is inteIDRreted as employee costs and human capital efficiency (HCE) calculated by dividing Value Added (VA) with Human capital (HC), calculated by the following formula:

Human Capital Efficiency $(\mathrm{HCE})=\frac{\text { Value Added }}{\text { Human Capital }}$

Structural Capital Efficiency (SCE). Structural capital (SC) is the difference between the value added (VA) produced and human capital (HC). Structural capital efficiency (SCE) is calculated by structural capital (SC) with Value Added (VA), calculated using the following formula:

Structural Capital Efficiency (SCE) $=\frac{\text { Structural Capital }}{\text { Value added }}$

Where, SCE is structural capital efficiency = value ratio SC and VA. Value Added Intellectual Coefficient (VAICTM) is the sum of HCE, SCE and CEE.

\subsubsection{Variable Capital Adequacy (X2)}

Capital adequacy is the obligation to provide minimum capital for commercial banks determined by Bank Indonesia. The formula that capital adequacy will be reflected in the capital structure that shows the combination of debt and equity in financing the assets of a company is called leverage. The indicator of capital adequacy is Total Debt to Total Asset Ratio (DAR), Debt to Equity Ratio (DER), Capital Adequacy Ratio (CAR). Total debt to total assets ratio (DAR) is a ratio of total liabilities to total assets. The total debt to total assets ratio (DAR) is used to measure how much a company's assets are financed by debt. Referring to Cekresi (2013), and Chukwunweike et al. (2014) debt to assets ratio (DAR is calculated as follows: 


$$
D A R=\frac{\text { Total debt }}{\text { Total assets }} \times 100 \%
$$

Debt to equity ratio (DER) is the ratio of total liabilities to total equity. Debt to equity ratio (DER) is used to measure how much equity (equity) is a guarantee of total liabilities. Debt to equity ratio (DER) is calculated using the following formula:

$$
\text { DER }=\frac{\text { Total debt }}{\text { Total equity }} \times 100 \%
$$

Capital adequacy is predicted as a determinant of credit risk and financial performance.

\subsubsection{Credit Risk Variables (Y1)}

Credit risk is a change in the value of net assets due to changes in the ability of counter parties to fulfill agreed obligations. Bank Indonesia Regulation No. 15/12 / PBI / 2013 concerning Provisions on Minimum Capital Provision Requirements, inteIDRreting credit risk as a risk of loss due to failure of debtors or counter parties in fulfilling obligations to banks. Credit risk is measured by indicators of Non Performing Loans (NPL) and Loan Loss Provision (LLP). Referring to the study of Deelchand et al., (2009) and Epure et al., (2013).

NPL, or often referred to as problem loans, are loans that are categorized as special, doubtful, and stalled attention. In Islamic banking, the term NPL becomes NPF (Non Performing Financing). The higher the NPL ratio (or NPF), means the worse the credit quality of a bank. This NPL ratio indicates the ability of bank management in managing bank credit problems, the better the bank management manages the loan portfolio, will be reflected in the low NPL ratio. The Non Performing Loan (NPL) indicator is calculated using the following formula:

$$
\begin{aligned}
& \text { Non Performing Loan Gross (NPLG) }=\frac{\text { Total Non Performing Loan (NPL) }}{\text { Total Gross Loan }} \\
& \text { Non Performing Loan Net (NPLN) }=\frac{\text { Total Non Performing Loan (NP) }}{\text { Total Net Loan }}
\end{aligned}
$$

Loan Loss Provision (LLP) is a provision or reserve formed to anticipate bank losses due to credit deterioration. As with the NPL, the higher LLP indicates deteriorating credit quality. The higher the NPL, the LLP will increase so that the subsequent impact will reduce the bank's income, because the formation of its source reserves comes from income or Net Interest Income (NII). LLP in Indonesian banking uses the term Allowance for Impairment Losses or Earning Activity Allowance. The Loan Loss Provision (LLP) indicator is calculated using the following formula:

$$
\text { Loss Provision (LLP) }=\frac{\text { Total Loss Provision (LLP) }}{\text { Total Kredit }}
$$

\subsubsection{Variable Financial Performance (Y2)}

Financial performance is the company's ability to manage assets owned and generate profits. Financial performance is measured by earnings per share (EPS) indicators, return on assets (ROA), return on equity (ROE), and net interest margin (NIM). The indicator of earnings per share (EPS) is the amount of net income after tax available to common stock owners. EPS is calculated as follows:

$\mathrm{EPS}=\frac{\text { Earnig after tax }}{\text { Common share outstanding }} \times 100 \%$

Return on assets (ROA) is a comparison of net income with total assets in a given time. Return on assets (ROA) is used to measure the ability of a company to manage assets to generate profits for the company, so it can increase the company's financial capacity to fund projects that have a positive "net present value". Referring to the study of Umar et al., (2012); Bokhari and Khan (2013) Return on assets (ROA) is calculated by the following formula:

$$
\mathrm{ROA}=\frac{\text { Earnig after tax }}{\text { Total assets }} \times 100 \%
$$

Return on equity (ROE) is a comparison of net income after tax with total equity in a certain time. Return on equity (ROE) is used to measure the ability of a company to obtain net income after tax that is available to equity owners, so as to increase the wealth of shareholders, consequently investors can assess management efficiency. Referring to Barakat's research (2014). Return on equity (ROE) is calculated using the following formula:

ROE $=\frac{\text { Earnig after tax }}{\text { Equity }} \times 100 \%$

Net interest margin (NIM) is a comparison between net interest income and average productive assets (loan portfolio that earns interest) in a given financial reporting period. NIM is used to measure the ability of banks to obtain net interest income, which is the difference between the total interest income and the total interest expense (interest income and interest expenses). The NIM is a measure of the ability of banks to establish funding policies (diversification of funding sources) that affect the structure of the cost of funds, basic credit interest rates, and credit policies (credit portfolio and lending rate). The higher the NIM shows that banks are getting better at managing third party funding sources (debt), channeling them into credit asset portfolios (investment side), including a more competitive lending rate policy. Net interest margin (NIM) (SE.BI.No.13 / 30 / DPNP / 2011) is 
calculated using the following formula:

\subsection{Population and Sample}

The location of this study in Indonesia and the object of observation are all bank industry companies listed on the Indonesia Stock Exchange. The population in this study is all manufacturing industry companies in Indonesia Stock Exchange (IDX), with observation period from 2012 to 2016 amounted to 43 bank. Sampling using a purposive method is the researcher determines the specific criteria or goals for the sample to be studied (Indriantoro and Supomo 1999: 146). The study is limited for the period 2012 to 2016 . The unit of analysis using data from 31 bank multiplied by 5 years is 155 financial statements. Pooling data time series and cross-section.

\subsection{Data Collection Method}

The data collection method used in this study is the documentation method. The documents that will be used in this study are audited financial statements by public accountants and annual reports, bank financial performance profiles, and fact book of Indonesia stock exchanges in 2012-2016. The type of data used in this study is secondary data in the form of financial report documents and company annual reports, which are sourced from the Indonesia Stock Exchange through the site http://www.idx.co.id.

\section{Research Findings}

\subsection{Description of Research Variables and Indicators}

Descriptive statistical analysis aims to describe data that has been collected as it is without intending to take general conclusions or generalizations. The data described is in the form of a minimum value, the maximum value, the average of each indicator forming latent variables, as listed in table 1, below:

Table 1. Description of Research Data

\begin{tabular}{|c|c|c|c|c|c|c|c|c|c|}
\hline \multirow[t]{2}{*}{ No } & \multirow{2}{*}{$\begin{array}{l}\text { Variables / } \\
\text { Indicators }\end{array}$} & \multicolumn{5}{|c|}{ Average per year } & \multicolumn{3}{|c|}{ Average in 5 years } \\
\hline & & 2012 & 2013 & 2014 & 2015 & 2016 & Min & Max & Mean \\
\hline \multirow[t]{5}{*}{1} & \multicolumn{9}{|c|}{ Intellectual capital (X1) } \\
\hline & $\operatorname{HCE}(\mathrm{x})$ & 2,58 & 2,00 & 1,93 & 1,89 & 1,52 & $-1,52$ & 4,19 & 1,98 \\
\hline & $\mathrm{SCE}(\mathrm{x})$ & 0,55 & 0,37 & 0,37 & 0,31 & 0,23 & $-2,10$ & 0,85 & 0,37 \\
\hline & $\mathrm{CEE}(\mathrm{x})$ & 0,40 & 0,30 & 0,32 & 0,21 & 0,14 & $-0,64$ & 1,23 & 0,27 \\
\hline & VAIC (x) & 3.54 & 2.67 & 2.62 & 2.41 & 1.89 & -4.26 & 6.27 & 2.62 \\
\hline \multirow[t]{4}{*}{2} & \multicolumn{9}{|c|}{ Capital Adequacy (X2) } \\
\hline & $\operatorname{DAR}(\mathrm{x})$ & 0,88 & 0,89 & 0,88 & 0,87 & 0,85 & 0,78 & 0,93 & 0,87 \\
\hline & $\operatorname{DER}(\mathrm{x})$ & 17,34 & 16,85 & 12,43 & 18,12 & 19,71 & 9,35 & 27,07 & 16,89 \\
\hline & CAR (\%) & 8,52 & 8,27 & 7,98 & 7,91 & 6,34 & 3,64 & 13,82 & 7,80 \\
\hline \multirow[t]{4}{*}{3} & \multicolumn{9}{|c|}{ Credit Risk (Y1) } \\
\hline & NPLG (\%) & 1,35 & 1,33 & 1,56 & 1,72 & 1,99 & 0,13 & 4,70 & 1,59 \\
\hline & NPLN (\%) & 2,36 & 2,41 & 2,66 & 2,85 & 3,74 & 0,42 & 11,84 & 2,80 \\
\hline & LLP $(\%)$ & 1,74 & 2,32 & 1,02 & 1,72 & 2,46 & 0,05 & 6,92 & 1,85 \\
\hline \multirow[t]{5}{*}{4} & \multicolumn{9}{|c|}{$\begin{array}{l}\text { Financial Performance } \\
\text { (Y2) }\end{array}$} \\
\hline & EPS (IDR) & 193,28 & 205,12 & 208,36 & 202,17 & 170,19 & -112 & 939,31 & 195,83 \\
\hline & ROA (\%) & 1,70 & 1,37 & 1,13 & 0,79 & 0,45 & $-6,02$ & 3,58 & 1,09 \\
\hline & ROE (\%) & 14,84 & 11,17 & 7,93 & 4,51 & 5,06 & 49,40 & 24,96 & 8,70 \\
\hline & NIM (\%) & 7,01 & 5,92 & 5,57 & 4,96 & 5,36 & 1,50 & 11,64 & 5,76 \\
\hline
\end{tabular}

\subsection{Statistical Analysis of the GSCA Method}

Generalized structured component analysis (GSCA) was developed to avoid the disadvantages of PLS (partial least square), which is equipped with global optimization procedures and also maintains local optimization procedures (such as in PLS). This analysis approach uses the least square method in the parameter estimation process. The GSCA method can also be applied to effect $\mathrm{s}$ between complex variables (can be recursive and not recursive), involving higher-order components (factors) and multi-group comparisons. GSCA is a new method of component-based SEM, which can be applied to very small samples. GSCA can be used in structural models involving variables with reflective and or formative indicators.

\section{Data Analysis Steps}

1) Designing a structural model (effect between latent variables). Structural models that show the effect between latent variables based on the formulation of the problem or research hypothesis. 
2) Designing a measurement model is determining the nature of the indicators of each latent variable, whether reflexive or formative.

3) Construction of path diagrams in the research model.

4) Conversion of path charts into systems of equations, including:

a) Explaining the effect of latent variables and indicators, also called the measurement model, defines the characteristics of latent variables with indicators.

b) Explain the effect between latent variables (structural models), which describes the effect between latent variables based on the substantive theory of research. Without losing its general properties, it is assumed that latent variables and indicators or manifest variables are standardized, so that constants can be removed from the model (constant $=0$ ).

c) Parameter estimation. The parameter estimation method (estimation) is the least square method. The structural model and measurement model are integrated into one model, so the parameter estimation process is oriented towards minimizing the integrated residual model. Estimating parameters based on original sample data, including: Weight and Loading estimate is to get latent variable data, generally parameter estimation using eigen value and eigen vector approach. The path coefficient estimate is the coefficient of effect between latent variables, used by ALS. Parameter estimation Based on resampling data (bootstrap sample), including: Means from Weight, Loading and Path coefficient, that is, the estimated parameter is a mean of subsample, using the bootstrap resampling method.

\subsubsection{Measurement Model Test Results}

Construct validity is needed to ensure that each indicator used in measuring latent variables is accurate and valid to represent or as a proxy for latent variables that have been arranged in the research model. The construct validity test for each indicator is done by referring to the level of significance of the "weight" value in the measurement model produced by the output analysis of the GSCA model. The test results obtained with GSCA Bootstrapping calculations. Detailed test results as in table 2. The next stage after evaluating construct validity for each indicator to measure the latent variable (independent and dependent) is to assess construct validity on the effect between the variables (inner model) arranged in this research model.

Table 2. Description of Measurement Model Test Results

\begin{tabular}{|c|c|c|c|c|c|}
\hline \multirow[b]{2}{*}{ Variables } & \multirow[b]{2}{*}{ Indicators } & \multicolumn{4}{|c|}{ Weight } \\
\hline & & Estimate & $\mathrm{SE}$ & $\mathrm{CR}$ & Information \\
\hline \multirow{4}{*}{$\begin{array}{l}\text { Intellectual } \\
\text { Capital (X1) }\end{array}$} & Capital Employed Efficiency (CEE) & 0.430 & 0.120 & $3.59 *$ & Significant \\
\hline & Human Capital Eficiency (HCE) & 0.667 & 0.091 & $7.33 *$ & Significant \\
\hline & Structural Capital Efficiency (SCE) & 0.543 & 0.126 & $4.30 *$ & Significant \\
\hline & Value Added Intellectual Coefficient (VAIC) & 0.897 & 0.057 & $15.84 *$ & Significant \\
\hline \multirow{3}{*}{$\begin{array}{l}\text { Capital } \\
\text { Adequacy (X2) }\end{array}$} & Debt to Assets Ratio (DAR) & 0.884 & 0.027 & $32.31 *$ & Significant \\
\hline & Debt to Equity Ratio (DER) & 0.851 & 0.021 & $40.87^{*}$ & Significant \\
\hline & Capital Adequacy (CAR) & 0.700 & 0.062 & $11,37^{*}$ & Significant \\
\hline \multirow{3}{*}{$\begin{array}{l}\text { Credit Risk } \\
\text { (Y1) }\end{array}$} & Non Performing Loan Gross (NPLG) & 0.882 & 0.028 & $31.14 *$ & Significant \\
\hline & Non Performing Loan Net (NPLN) & 0.467 & 0.152 & $3.08^{*}$ & Significant \\
\hline & Loan Loss Provision (LLP) & 0.488 & 0.141 & $3.47 *$ & Significant \\
\hline \multirow{4}{*}{$\begin{array}{l}\text { Financial } \\
\text { Performance } \\
(\mathrm{Y} 2)\end{array}$} & Earning Per Share (EPS) & 0.539 & 0.057 & $9.5^{*}$ & Significant \\
\hline & Return on Assets (ROA) & 0.864 & 0.049 & $17.49 *$ & Significant \\
\hline & Return on Equity (ROE) & 0.800 & 0.038 & $20.79 *$ & Significant \\
\hline & Net interest margin (NIM) & 0.283 & 0.056 & $5.02 *$ & Significant \\
\hline
\end{tabular}

\subsubsection{Inner Model Testing Results}

Based on the theory and results of previous empirical research and conceptual models of research, the results of the inner model analysis are explained which show how each independent latent variable affects the dependent latent variable. The path coefficient on the effect between independent latent variables on the dependent latent variables is obtained through analysis of the GSCA model, including the "bootstrapping" process that produces the value of the critical ratio (CR) to ensure the significance of the effect of one variable with other variables. Based on the results of the GSCA output a hypothetical model was tested as shown by the path coefficients presented in table 3, as follows: 
Table 3. Hypothesis Test Results

\begin{tabular}{|c|c|c|c|c|c|r|}
\hline \multirow{2}{*}{ Hypothesis } & \multicolumn{3}{|c|}{ Path Coefficients } & \multicolumn{2}{c|}{ Information } \\
\cline { 2 - 5 } & Path & Estimate & $S E$ & $C R$ & \\
\hline $\mathrm{H} 1$ & $\mathrm{X} 1 \rightarrow \mathrm{Y} 1$ & -0.540 & 0.094 & $5.76^{*}$ & Significant & H1 Accepted \\
\hline $\mathrm{H} 2$ & $\mathrm{X} 1 \rightarrow \mathrm{Y} 2$ & 0.614 & 0.075 & $8.21^{*}$ & Significant & H2 Accepted \\
\hline $\mathrm{H} 3$ & $\mathrm{X} 2 \rightarrow \mathrm{Y} 1$ & 0.422 & 0.083 & $5.08^{*}$ & Significant & H3 Accepted \\
\hline $\mathrm{H} 4$ & $\mathrm{X} 2 \rightarrow \mathrm{Y} 2$ & 0.387 & 0.120 & $3.22^{*}$ & Significant & H4 Accepted \\
\hline $\mathrm{H} 5$ & $\mathrm{Y} 1 \rightarrow \mathrm{Y} 2$ & -0.269 & 0.076 & $3.57^{*}$ & Significant & H5 Accepted \\
\hline
\end{tabular}

$C R^{*}=$ significant at 0.05 level

Source: GSCA analysis results are processed in year 2018.

\section{Discusion}

This study discusses theoretically and empirically the phenomena facing the banking industry in Indonesia, through research on the effect of intellectual capital, and capital adequacy on credit risk and financial performance of companies. This study has 5 hypotheses which will be discussed as follows.

\subsection{The Effect of Intellectual capital on credit Risk}

The intellectual capital has a negative and significant effect on credit risk. The path coefficient value is -0.540 , the value of CR 5.76* is greater than 1.96; significant at the level of $\mathrm{P}=0.05$. The path coefficient value -0.540 , means that credit risk is determined by intellectual capital (human capital, structural capital, and capital employed) of $54.0 \%$, while the remaining $46.0 \%$ is determined by other variables and errors. The test results accept hypothesis 1 which states that "intellectual capital has an effect on credit risk." It means an improvement or increase in the value of investments made in the field of intellectual capital (human capital, structural capital, and capital employed) to produce aggregate efficiency in creating added value. the better, it will reduce the level of credit risk for the banking industry. The theoretical implication of this empirical finding is that intellectual capital will reduce the level of credit risk. The findings of this study support the research findings. This finding confirms the research concept of Ghosh and Maji (2014) in Indian banking, which reveals that intellectual capital efficiency (HCE and $\mathrm{SCE})$ has a negative and significant effect on credit risk.

\subsection{The Effect of Intellectual Capital on Financial Performance}

The Intellectual capital has a positive and significant effect on financial performance. The path coefficient value is 0.614 , the value of CR $8.21^{*}$ is greater than 1.96; significant at the level of $\mathrm{P}=0.05$. The path coefficient value is 0.614 , meaning that financial performance is determined by intellectual capital (human capital, structural capital, and capital employed) of $61.4 \%$, while the remaining $38.6 \%$ is determined by other variables and errors. The test results accept hypothesis 2 which states that "intellectual capital has an effect on financial performance". This means that the improvement or increase in the value of investments made in the field of intellectual capital (human capital, structural capital, and capital employed) to produce aggregate efficiency in creating better added value, will improve the financial performance of the banking industry. The theoretical implication of this empirical finding is that intellectual capital will improve financial performance. The findings of this study support and confirm the research concept of Asadi (2013) which states that intellectual capital and its components have a significant effect on the company's financial performance. The findings of this study are also the empirical findings of research conducted by previous researchers which revealed that intellectual capital had a significant effect on financial performance (Sudaryono et al., 2012, banks listed on the IDX. Non-banking companies were listed on the Tehran stock exchange (Japari, 2013). some of the research findings conducted by Yu et al., (2010) in companies recorded in the Hangseng Index, on the Hong Kong Stock Exchange, revealed that the intellectual capital component (structural capital, and capital employed) can predict a variety of business performance substantively and positively.

\subsection{The Effect of Capital Adequacy on Credit Risk}

The capital adequacy has a positive and significant effect on credit risk. Path coefficient value 0.422 , CR value $8.21^{*}$ greater than 1.96; significant at the level of $\mathrm{P}=0.05$. The path coefficient value is 0.422 , meaning that credit risk is determined by capital adequacy (DAR, DER, CAR) of $42.2 \%$, while the remaining $57.8 \%$ is determined by other variables and errors. The test results accept hypothesis 3 which states that "Capital adequacy has an effect on credit risk". This means that changes in the capital adequacy ratio will cause changes in credit risk in the banking industry.

The increase in credit risk was more due to the growth in lending in line with the increase in nominal capital adequacy, and an increase in the potential for bad loans. This finding is consistent with Capital buffer theory 
Marcus (1984) referred to by Heid (2004), Deelchan et al., (2009) which states that capital adequacy has an effect on credit risk, meaning that any increase in capital adequacy will be followed by increases in credit risk and vice versa. This finding also confirms the findings of previous researchers conducted by Jokipii and Milne (2009) in the United States banking sector in the period 1986 - 2006, and Bichsel and Blum (2002) in the Swiss banking sector in the period 1990 - 2002, which stated that capital adequacy had an effect on increase in credit risk.

\subsection{The Effect of Capital Adequacy on Financial Performance}

The capital adequacy has a positive and significant effect on financial performance. The path coefficient value is 0.387 , the value of CR $8.21^{*}$ is greater than 1.96; significant at the level of $\mathrm{P}=0.05$. Path coefficient value 0.387 , meaning that financial performance is determined by capital adequacy (DAR, DER, CAR) of $38.7 \%$, while the remaining $61.3 \%$ is determined by other variables and errors. The test results accept hypothesis 4 which states that "capital adequacy has an effect on financial performance". This means that changes in the capital adequacy ratio will lead to an increase in the financial performance of the banking industry. Rationally it can be explained that the increase in capital adequacy (the share of equity increases against liabilities) will encourage banks to expand credit, and will increase interest income. the theoretical implication of this empirical finding is that capital adequacy will improve financial performance.

This finding confirms Agency theory (Jensen and Meckling, 1976) which states that the use of debt can reduce agency costs and increase profitability. At the same time, it also confirms the empirical findings of research conducted by Berger and Bouwman (2011) in the United States banking period 1984 - 2009, and empirical findings from the results of Epure et al., (2013) in the Costarika banking sector in the period 1998 - 2007.

\subsection{The Effect of Credit Risk on Financial Performance}

Credit risk has a negative and significant effect on financial performance. Path coefficient value -0.269 , CR value $3.57^{*}$ greater than 1.96; significant at the level of $\mathrm{P}=0.05$. The path coefficient value is -0.269 , meaning that the financial performance is determined by credit risk of $38.7 \%$, while the remaining $-26.9 \%$ is determined by other variables and errors. The test results accept hypothesis 5 which states that "Credit risk has an effect on financial performance". This means that increase in the level of credit risk will cause a decrease in the level of financial performance of the banking industry. This means that any increase in potential credit risk that appears in the increase in the NPL ratio and the increase in reserves for impairment losses or loan loss provisions (LLP) will reduce financial performance. The decline in financial performance was caused by the increase in the number of LLP which was a deduction for the amount of bank operating income. The theoretical implication of this empirical finding is that an increase in credit risk will reduce financial performance.

This finding confirms the research concepts of Mendoza and Rivera (2017) in the rural banking sector in the Philippines, also supports the empirical findings of previous research studies conducted by Epure et al., (2013) in Costarika banking, and Amidu et al., (2006) in banking Ghana, both of which state that credit risk affects financial performance (profitability and ROA) in a negative direction.

This finding does not support "Bearing Risk Theory" developed by Hawley (1900) explaining that an important function of an entrepreneur is taking risks, a function that cannot be delegated to others. Hawley argues that profit is a gift for risk takers. Bearing Risk Theory further states that some risks are inherent in each speculative business company in the business view. So, in the banking business, management must bear the risk of earning profits in return for risk taking. Hawley (1900) states that risk levels vary in different businesses, but there is a positive relationship between risk and profit.

\section{Conclusion}

The Intellectual capital has a significant effect on the negative direction of credit risk. This finding supports the research concept of Ghos and Maji (2014) which states that intellectual capital has a negative effect on credit risk. The company maximizes intellectual capital and continues to increase the level of Intellectual capital, thereby reducing credit risk.

The Intellectual capital has a significant effect with a positive direction on financial performance. This finding supports the research concept of Asadi (2013) which states that intellectual capital and its components have a significant effect on financial performance, and confirm the findings of research conducted by Japari (2013) and Sudaryono et al., (2012). It means that the increase or improvement of intellectual capital increases financial performance. If the company utilizes the Intellectual capital to its full potential, the company's financial performance will be higher.

The Capital adequacy has a significant effect with a positive direction on credit risk. This finding confirms capital buffer theory (Marcus, 1984) referred to and described by Heid (2004) and Deelchan, et al (2009), which states that capital adequacy has an effect on credit risk, in the sense that the level of credit risk increases, the bank will increase the capital adequacy ratio. Conversely, any increase in capital adequacy has the potential to increase lending with credit risk that will increase. This finding confirms the results of the research of Jokipii and Milne 
(2009), Bichsel and Blum (2002).

The Capital adequacy has a significant effect with a positive direction on financial performance. This finding supports the agency theory Jensen and Meckling (1976), referenced and described by Berger et al., (2002) which states that higher "leverage" (lower portion of equity) will reduce agency costs outside equity, and affect performance finance (higher profit) with the condition of citeris paribus. This finding confirms the results of the study: Berger et al., (2011) in banks in the United States in the period 1984 - 2009 and Epure et al. (2012) in Costarika peroide banking in 1998 - 2007.

The Credit risk has a significant effect on the negative direction of financial performance. This finding supports the concept of Mendosa and Rivera (2017) research, which states that credit risk has a significantly negative effect on financial performance (profitability). This finding also confirms the results of Epure, et al (2013) and the results of Amidu et al., (2006).

\section{Recommendations}

\subsection{Recommendations for the Future Research}

Based on the discussion of the findings and limitations of this study which have been described in the previous section, it is recommended that future research be as follows:

1) Future research can add other variables that have not been included in this research model, to obtain a more comprehensive research model. For example, corporate governance variables, investment policies and macroeconomic variables such as inflation rates, interest rates, national income.

2) Further research can be done elsewhere in a longer time, or replace other research objects.

\subsection{Recommendations for Companies and Investors}

Practically recommended for companies and investors, it is recommended as follows:

1) Management must consider intellectual capital, capital adequacy, credit risk in order to improve financial performance. Furthermore intellectual capital can be a reference in determining the funding mechanism, whether to use internal funds or external funds.

2) Companies can use internal funds before external funds, because the internal funds are free of additional interest costs

3) Companies, if they want to use external funds from debt, they must consider liquidity so that the company does not experience difficulties in repaying debt that is due. High liquidity can reduce the level of debt, because debt has interest costs, then reducing interest costs can improve financial performance and corporate value.

4) Management must consider credit risk, because credit risk is uncertainty that has a negative impact on financial performance.

5) Companies, if they want to use debt, they must choose a low cost level so that they do not burden the company with high interest costs and the risk of failure.

6) Management must maintain and improve financial performance, because investors will value shares of companies that have high financial performance at the highest prices.

7) Management must integrate financial data and other relevant information for the sake of analysis in producing more precise predictions, to overcome the limitations of information in financial statements, in order to produce more precise predictions.

\section{References}

Abbas, A., Haider, A and Rana, U. A. (2014). Credit risk exposure and performance of banking sector of Pakistan. Journal of Basic and Applied Sciences, Vol. 4(3): 240-245.

Abdelrahim, K. E. (2013). Effectiveness of credit risk management of Saudi Banks in the light of global financial crisis: a qualitative study. Asian Transactions on Basic and Applied Sciences, Vol. 3 (2): 73-91.

Abiola, I. and Olausi, A.S. (2014). The impact of credit risk management on the commercial banks performance in Nigeria. International Journal of Management and Sustainability, Vol. 3 (5): 295-306.

Abbazadeh, M., Amiri, R. A., Azimi, J., Jazdanifar, N. and Shurokey, M. R. (2013). The relationship between capital structure and the efficiency in both state and private banks by the Use of DEA Technique. International Journal of Academic Research in Accounting, Finance and Management Sciences., Vol. 3, No. 4, October 2013, pp 51-60.

Adeusi, S.O., Akeke, N. I., Adebisi, O.S. and Oladunjoye, O. (2013). Risk management and financial performance of banks in Nigeria. Journal of Business and Management, Vol. 14 (6): 52-56.

Aduda, J. and Gitonga, J. (2011). The relationship between credit risk management and profitability among the commercial banks in Kenya. Journal of Modern Accounting and Auditing, Vol. 7 (9): 934-946.

Akhtar, M. F., Ali, K., and Sadaqat, S. (2011). Factors influencing the profitability of Islamic banks of Pakistan. International Research Journal of Finance and Economics, 66, 125-132.

Alshatti, Ali Sulieman. (2015). The effect of credit risk management on financial performance of the Jordanian 
commercial banks. Investment Management and Financial Innovations, 12(1-2): 338-345.

Ali, K., Akhtar, M. F., and Ahmed, H. Z. (2011). Bank-specific and macroeconomic indicators of profitability: Empirical evidence from the commercial banks of Pakistan. International Journal of Business and Social Science, Vol. 2(6): 235-242.

Aremu, M. A., Ekpo, I. C., and Mustapha, A. M. (2013). Determinants of banks' profitability in a developing economy: evidence from Nigerian banking industry. Interdisciplinary Journal of Contemporary Research in Business, Vol. 4(9): 155-181.

Altumbas,Yener, Santiago Carbo, Edward P. M. Gardener and Philip Molyneux. (2007). Examining the relationship between capital, risk and efficiency in European banking. European Financial Management, Vol.13 (1): 49-70.

Amidu, Mohammed, Robert, Hinson. (2006). Credit risk, capital structure and lending decisions of banks in Ghana. Banks and bank system, Vol.1. Issue 1, 2006.

Amir Moradi-Motlagh., Saleh, Ali Salman., Abdekhodaee, Amir and Ektesabi, Mehran. (2011). Efficiency, effectiveness and risk in Australian banking industry. World Review of Business Research, Vol.1 (3): 1-12.

Aruwa, S. A. and Musa, O. A. (2014). Risk components and the financial performance of deposit money in Nigeria. International Journal of Social Sciences and Entrepreneurship, Vol. 1 (11): 1-8.

Asadi, Leila. (2013). The effect of intellectual capital on market value and financial performance, of companies listed at Tehran stock exchange. Science Road Publishing Corporation, 7 (1): 48-58.

Athanasoglou, Panaiyotis P. (2011). Bank capital and risk in the bank of Greece. South Eastern European Region. Munich Personal RePEc Archive Paper No.32002, posted 4 July, 2011.

Aymen. (2015). The relasionship between Capital and Bank Risk, Evidence from Tunisia.

Bank Indonesia. SE No.13/30/DPNP dated 16 December 2011 concerning the Third Amendment to Bank Indonesia Circular Number 3/30 / DPNP dated 14 December 2001 concerning Quarterly and Monthly Publication Financial Reports for Commercial Banks and Certain Reports Submitted to Bank Indonesia. https://www.bi.go.id.

Bank Indonesia Regulation Number 13/1/PBI/2011 concerning Soundness Rating for Commercial Banks. https://www.bi.go.id.

Bank Indonesia Regulation Number 15/2 / PBI / 2013 dated May 20, 2013 concerning Determination of Status and Follow-Up to Supervision of Conventional Commercial Banks. https://www.bi.go.id.

Bank Indonesia Regulation No.15 / 12 / PBI / 2013 concerning the Minimum Capital Requirement for Commercial Banks. State Gazette R.I. In 2013, No.223 DPNP.

Barakat, Abdallah. (2014). The impact of financial structure, financial leverage and profitability on industrial companies shares value (applied study on a sample of Saudi industrial companies). Research Journal of Finance and Accounting, Vol. 5 (1): 55-66.

Basle I Committee on Banking Supervision, International Convergence of Capital Measurement and capital Standard. (1988). Bank For International Setlement, Basle, Switzerland.

Basle II, Consultative document, Pillar 3 (Market Discipline), supporting document to the New Basel Capital Accord, 2001. Bank For International Setlement, Basle, Switzerland.

Basel III: A global regulatory framework for more resilient banks and banking systems, December 2010 (rev June 2011). https://www.bis.org/bcbs/publ/d424.htm.

Basel Committee on Banking Supervision. (2015). Bank for International Settlements. This publication is available on the BIS website (www.bis.org).

Berger, A.N. and Bouwman, C. H. S, (2011). How does capital affect bank performance during financial crises?. Journal of Financial Economics, 109 (2013) 146-176.

Berger A.N., Herring R.J., and Szego, G. (1995). The role of capital in financial institutions. Working Paper 95 01., JEL classification codes: G21, G28, G32, E58, L89.

Berger, A. N and Dipati, E.B. (2002). Capital structure and firm performance: a new approach to testing agency theory and an application to banking industry. JEL Codes: G.32, G.34,G.21,G.28.

Berglund, Robin., Gronval.T. and Johnson M. (2002). Intellectual capital's leverage on market value. Lund Schoolof Economics and Management, Lund University.

Berríos, Myrna R. (2013). The relationship between bank credit risk and profitability and liquidity. The International Journal of Business and Finance Research, Vol. 7 (3): 105-118.

Bischsel and Blum. (2002). The Relationship between risk and capital in Swiss commersial banks: A Panel Study, Working Paper No. 02. 04., Sptember, 2002.

Boahene, S.H., Dasah, J. and Agyei, S.K. (2012). Credit risk and profitability of selected banks in Ghana. Research Journal of Finance and Accounting, Vol. 3 (7): 6-15.

Bokhari, Haseeb Wadood and Khan, Muhammad Arif. (2013). The impact of capital structure on firm's performance a case of financial sector of Pakistan. European Journal of Business and Management, Vol. 5 (31): 111-137. 
Brooking, A. (1996). Intellectual Capital, Core Asset For The Third Millennium Enterprise. London: International Thomson Business Press.

Çekrezi, Anila. (2013). Impact of firm specific factors on capital structure decision: An empirical study of Albanian firms. European Journal of Sustainable Development, Vol. 2 (4). 135-148.

Chen, M., Cheng, S., and Huang, Y. (2005). An empirical investigation of relationship between intellectual capital, and firm's market value and financial performance. Journal of Intellectual Capital, Vol.6 (2): 159-176.

Christaria, Fiola and Kurnia, Ratnawati. (2016). The impact of financial ratios, operational efficiency and nonperforming loan towards commercial bank profitability. Accounting and Finance Review. Vol. 1 (1) 4350.

Chukwunweike, Ehiedu Victor and Osiegbu, Patrick I. (2014). Capital structure and performance evaluation in manufacturing sector: A case study of selected quoted companies in the Nigeria stock exchange (NSE). Research Journal of Finance and Accounting, Vol. 5 (6): 35-40.

Çelikkol, H. (2008). Entellektu“el sermayenin €olçu“lmesi. In R. As,1koglu, M. Kurt, \& K. Ozcan (Eds.), € Entelektu"el sermaye: Teori, uygulama ve yeni perspektifler (pp. 60-90). Ankara: Gazi Kitabevi.

Deelchan, Tara and Padgett, Carol. (2009). The relationship between risk, capital and efficiency: evidence from Japanese cooperative banks. ICMA Centre discussion Paper in Finance, DP.2009-12.

Deep, R and Narwal, K. Pal. (2014). Intellectual capital and its association with financial performance: a study of Indian textile sector. International Journal of Management and Business Research, Vol. 4 (1): 43-54.

Edvinsson, L. (1997). Developing intellectual capital at Skandia. Long Range Planning, 30 (3): 320-373. Economic Times Bureau, 2010. What is capital adequacy ratio? from http:/economictimes.indiatimes. com/all-about-capital-adequacy-ratio/what-is-capital-adequacy-ratio/slideshow/6222228.cms

Epure, M. and Esteban, L. (2013). Monitoring bank performance in the presense of risk. Barcelona GSE Working Paper Series, No.613, JEL Classification G21,G28, G3, M1, M2.

Erina, J., and Lace, N. (2013). Commercial banks profitability indicators: empirical evidence from Latvia. IBIMA Business Review, 2013, 1-9. doi: https://doi.org/10.5171/2013.873515

Flamini, V., McDonald, C and Schumacher, L. (2009). The determinants of commercial bank profitability in SubSaharan Africa IMF Working Paper, Vol. 09(15): 1-30.

Gakure, R.W., Ngugi, J. K., Ndwiga, P. M. and Waithaka, S. M. (2012). Effect of credit risk management techniques on the performance of unsecured bank loans employed commercial banks in Kenya. International Journal of Business and Social Research, Vol. 2 (4): 221-236.

Gestel, T.V. and Baesens, B. (2008). Credit Risk Management Basic Concepts: Financial Risk Components, Rating Analysis, Models, Economic And Regulatory Capital. Oxford University Press.

Gizaw, Million., Kebede, Matewos., and Selvaraj, Sujata. (2015). The impact credit risk on profitability performance of commercial banks in Etiopia. African Journal of Business Management. Vol. 9(2) : 59-66.

Gizycki, Mariane, and Goldsworthy, B. 1999). Australian banking risk: The stock market assessment and the relationship between capital and assets volatility". Research Discussion Paper,1999-9 , Nopember 1999, Reserve Bank of Australia.

Goh, Pek Chen. (2005). Intellectual capital performance of commercial banks in Malaysia. Journal of Intellectual capital, Vol.6 (3):385- 396.

Gohar, R. and Shohaib, Adam. (2011). Achieving the optimal capital structure and its impact on Pakistani banking performance. International Review of Business Research Paper, Vol. 7 (3): 9-24.

Gosh, Santanu Kumar and Maji, Santi. (2014). The impact of intellectual capital on bank risk: Evidence from Indian banking sector. The IUP Journal of Financial Risk Management, IJFRM21409.

Grant, Robert M. (1996). Toward a knowledge based theory of the firm. Strategic Management Journal, Vol. 17 (Winter Special Issue ): 109-122.

Haneef, S., Riaz, T., Ramzan, M., Rana, M. A., Hafiz, M. I., \& Karim, Y. (2012). Impact of risk management on nonperforming loans and profitability of banking sector of Pakistan. International Journal of Business and Social Science, Vol. 3 (7).

Hantono. (2017). Effect of capital adequacy ratio (car), loan to deposit ratio (LDR) and non performing loan (NPL) to return on assets (ROA) listed in banking in Indonesia stock exchange. International Journal of Education and Research, Vol. 5 (1) : 69-80.

Hawley, F. B. (1900). Enterprise and profit. Quarterly Journal of Economics, Vol. 15(1): 75-105.

Heid, Frank., Porath, D., and Stolz, S. (2004). Does capital regulation matter for bank behaviour? Evidence for German savings banks., Discussion Paper Series 2: Banking and Financial Supervision No 03/2004. Deutsche Bundesbank, Wilhelm-Epstein-Strasse 14, 60431 Frankfurt.

Hosna, A. and Manzura, B. and Juajuan, S. (2009). Credit risk management and profitability in commercial banks in Sweden, Master Theses. Available at: https://Gupea.ub.gu.se. Handle. Net

Iloska, N. (2014). An analysis of bank profitability in Macedonia. Journal of Applied Economics and Business, Vol. 2 (1): 31-50. 
Indriantoro, Nur dan Supomo, Bambang. (1999). Business Research Methodology. BPFE-Yogyakarta.

Jablecki, Juliusz. (2009). The impact of Basel I capital requirements on bank behavior and the efficacy of monetary policy. International Journal of Business and Economic Sciences Applied Research (IJBESAR), Vol. 2 (1): 16-35.

Japari, Eskandar. (2013). Intellectual capital and its effects on firms' market value and financial performance in Iran: an investigating pulic model. Research Journal of Recent Sciences, 2 (3): 1-6.

Jensen, Michael C. and Meckling, W. H. (1976). Theory of the firm: Managerial behavior, agency cost and ownership structure. Journal of Financial Economics, Vol. 3 (4): 305-360.

Jokipii, T. and Milne, A. (2009). Bank capital buffer and risk adjusment decisions. Swiss National Bank Working Papers, 2009-9.

Joshi, M., Cahill, D., Sidhu, J and Kansal, M. (2013). Intellectual capital and financial performance: an evaluation of the Australian financial sector. Journal of Intellectual Capital, Vol. 14 (2): 264-285.

Kaaya, I. and Pastory, D. (2013). Credit risk and commercial banks performance in Tanzania: a panel data analysis. Research Journal of Finance and Accounting, Vol. 4 (16): 55-63.

Kaplan, R. S., and Norton, D. P. (1996). The Balanced Scorecard: Translating Strategy Into Action. Boston: Harvard Business School Press.

Karacan, S and Ergin, E. (2011). Bankaların entelektu“el sermayesi ile finansal performansı arasındaki ilis,ki. Business and Economics Research Journal, Vol. 2(4): 73-88.

Kasmir (2014). Banking Basics. Ed. Revision. PT Raja Grafindo Persada. Jakarta.

Kayacan, M and Alkan, N. (2005). Tu“Rkiye'deki Bes,Eri Sermayenin Ekonomik Degeri Ve Avrupa Birligi U“Lkeleri Ile Kars, Ilas, Tirilması. Ankara: Ziraat Bankası A.S, (Yayınlari).

Kithinji, A.M. (2010). Credit risk management and profitability of commercial banks in Kenya. Working Paper, School of Business University of Nairobi, Kenya. Available at: http://erepository.uonbi.ac.ke.

Kochubey, T and Kowalczyk, D. (2014). The relationship between capital, liquidity and risk in commercial banks. The Ninth Young Economist Seminar, by The Croasian National Bank. Mei 14, 2014., JEL Clasification; G21, G28.

Kurawa, Junaidu Muhammad and Garba, Sunusi. (2014). An evaluation of the effect of credit risk management (CRM) on the profitability of Nigerian banks. Journal of Modern Accounting and Auditing, Vol. 10 (1): $104-$ 115.

Kurt, M. (2008). Entellektüel sermayenin temel unsurları. In R. As,1koglu, M. Kurt, \& K. Ozcan (Eds.), Entelektu“el sermaye: Teori, uygulama ve yeni perspektifler (pp. 30e44). Ankara: Gazi Kitabevi.

Lapteva, M.N. (2009). Credit risk management in the bank, letter from the bank of Russia 'on typical banking risks'. Available at: https://www.google.jo.

Macerinskiene, I., and Survilaite, S. (2013). The asses model of intellectual capital and company's value added cohesion. IJAFM, Universal Research Group, Vol. 6 January 2013.

Maurin, L and Toivanen, M. (2012). Risk, capital buffer and bank lending a granular approach to the adjusment of Euro Area Bank. Working Paper Series, No 1499 / november 2012, http://www.ecb.europa.eu.

Marcus, A. J. (1984). Deregulation and bank financial policy. Journal of Banking and Finance, Vol. 38: 557-565.

Mbarek, Lassaad, and Hmaied,DM. (2011). Stock market assessment of bank risk: Evidence from the Magreb Region. Economic Research Forum, March, 2012.ERF 18th Annual Conference, Cairo.

Meles, A., Porzio, C., Sampagnaro, G. and Verdoliva, V. (2016). The impact of intellectual capital efficiency on Comercial banks performance: evidence from the US. Department of Business and Quantitative Studies, Via G. Parisi,13, 80132.

Mendoza, R. and Rivera, J. P. R. (2017). The effect of credit risk and capital adequacy on the profiability of rural banks in the Phillippines. Scientific Annals of Economics and Business, Vol. 64 (1): 83-96.

Mingo, John J. (2000). Policy implications of the Federal Reserve study of credit risk models at major US banking institutions. Journal of Banking and Finance, Vol. 24 (1-2): 15-33.

Modigliani, Franco, and Miller, Merton H. (1963). Corporate income taxes and the cost of capital: a correction. American Economic Review, Vol. 53 (3): 433-443.

Mondal, Amitava, and Gosh, S. Khumar. (2012). Intellecutal capital and financial performance of Indian Banks. Journal of Intellectal Capital, Vol.13 (4): 515-530.

Musyoki, D. and Kadubo, A.S. (2012). The impact of credit risk management on the financial performance of Banks in Kenya for the period (2000-2006). International Journal of Business and Public Management, Vol. 2 (2): $72-80$

Naidu, Wesley. (2011). The application of capital structure theory and regulation for South African Banking Institution. Faculty of Economic and Management Sciences at The University of Pretoria, November, 2011.

Naceur, S. B. (2003). The determinants of the Tunisian banking industry profitability: panel evidence. Universite Libre de Tunis, Working Paper, 1-17. http://www.mafhoum.com/press6/174E11.pdf.

Nawaz, M. and Munir, S. (2012). Credit risk and the performance of Nigerian. Interdisciplinary Journal of 
Contemporary Research in, Vol. 4 (7): 49-63.

Njanike, K. (2009). The impact of effective credit risk management on bank survival. Journal of Financial Regulation and Compliance. Working Paper, Bindura University, Zimbabwe. Available at: https://ideas.repec.org.

Nuryaman. (2015). The effect of intellectual capital on the firm's value with the financial performance as intervening variable. Procedia - Social and Behavioral Sciences, Vol. 211 (2015): 292 - 298.

Obamuyi, T. M., 2013. Determinants of banks' profitability in a developing economy: Evidence from Nigeria. Organizations and Markets in Emerging Economies, Vol. 4(2): 97-111.

Ohlson, James A. (1995). Earnings, book values and devidends in equity valuation. Contemporary Accounting Research, Vol. 11(2): 661-687. Columbia University.

Ogboi, Ch. and Unuafe, O.K. (2013). Impact of credit risk management and capital adequacy on the financial performance of commercial banks in Nigeria. Journal of Emerging Issues in Economics, Finance and Banking, Vol. 2 (3):703-717.

Ozkan, Nasif., Cakan, Sinan., and Kayacan, Murad. (2017). Intellectual capital and financial performance: A study of the Turkish Banking Sector. Borsa Istanbul Review, Vol. 17 (3): 190-198.

Poraghajan, Abbasaly et al. (2013). Impact of intellectual capital on market value and firms' financial performance: evidences from Teheran Stock Exchange. World of Sciences Journal, Vol. 1 (12): 197-208.

Poudel, R.P. (2012). The impact of credit risk management on financial performance of commercial banks in Nepal, International Journal of Arts and Commerce, Vol. 1 (5): 9-15.

Prastiyaningtyas, F. (2010). Factors Affecting Banking Profitability. Jurnal. Jakarta.

Pulic, Ante. (1998). Measuring the performance of intellectual potential in knowledge economy. (presented in 1998 at the 2nd McMaster World Congress on Measuring and Managing Intellectual Capital by the Austrian Team for Intellectual Potential).

Pulic, Ante. (2004). Intellectual capital - does it create or destroy value?. Measuring Business excellence, Vol. 8 (1): $62-68$.

Pulic, Ante. (2008). The Principles of Intellectual capital efficiency a brief discription, in inspiredby knowlege in organizations: essays in honor of Professor Kan -Erik Sveiby on his 60th Birthday 29th June 2008.

Psillaki, Maria., Tsolas, Ioannis E. and Margaritis, Dimitris. (2015). Evaluation of credit risk based on firm performance. European Journal of Operational Research, Vol. 201 (3): 873-881.

Roman, A., and Danuletiu, A. E. (2013). An empirical analysis of the determinants of bank profitability in Romania. Annales Universitatis Apulensis Series Oeconomica, Vol. 15 (2): 580-593.

Roos, J., Roos, G., Dragonetti, N. C and Edvinsson, L. (1997). Intellectual Capital: Navigating In The New Business Landscape. London: MacMillan Press.

Samuel, K. W. Chu, et al. (2011). Charting intellectual capital performance of the geteway to China. Journal of Intellectual Capital, Vol.12 (2): 249-276.

Scott, J. W. and Arias, J. C. (2011). Banking profitability determinants. Business Intelligence Journal, Vol. 4 (2): 209-230.

Singh, A. (2013). Credit risk management in Indian commercial banks, International Journal of Marketing, Financial Services \& Management Research, Vol. 2 (7): 47-51.

Staikouras, C. K., and Wood, G. E. (2004). The determinants of European bank profitability. International Business and Economics Research Journal, 3(6), 57-68.

Steward, T. (1991). Intellectual capital: brainpower. Fortune, (June 3), 44.

Steward, T. A. (1997). Intellectual Capital: The New Wealth of Nations. New York: Doubleday Dell Publishing Group, Inc.

Skopljak, Vedran., and Luo, R. H. (2012). Capital structure and firm performance, in the financial sector: evidence from Australia. Asian Journal of Finance \& Accounting, Vol. 4 (1), ISSN 1946-052X.

Stephanou, Constantinos and Mendoza, Juan Carlos. (2005). Credit Risk Measurement Under Basel II: An Overview and Implementation Issues for Developing Countries. World Bank Policy Research Working Paper 3556, April 2005. pp 1-33.

Sudaryono, Bambang., Murtanto, dan Prihantini, A. (2012). Effect intellectual capital (VAIC) to market value and financial performance of banking sector companies listed in Indonesia Stock Exchange. The Conference of Business and Management 6-7 September 2012, Phuket Thailand.

Sudiyanto, B. (2010). Analysis of the effect of third party funds, BOPO, CAR, and LDR on financial performance in the banking sector that go public on the IDX. Jurnal Manajemen dan Bisnis Stiku bank, 2 (2).

Sveiby, K. E. (1997). The New Organizational Wealth: Managing And Measuring Knowledge-Based Assets. San Francisco, CA: Berrett-Koehler Publishers.

Umar, Muhammad. Tanveer, Zaighum. Aslam, Saeed. Sajid, Muhammad. (2012). Impact of capital structure on firms' financial performance: evidence from Pakistan. Research Journal of Finance and Accounting, Vol. 3 (9):1-12. 
Veltri, S. and Silvestri, A. (2011). Direct and indirect effect of human capital on firm value : evidence from Italian companies. Journal of Human resources costing \& Acconting, Vol. 15(3): 232-254.

Vong, A and Chan, H. S. (2009). Determinants of bank profitability in Macao. http://www.amcm.gov. mo/publication/quarterly/July2009/macaoprof_en.pdf.

Yalama, A., and Coskun, M. (2007). Intellectual capital performance of quoted banks on the Istanbul stock exchange market. Journal of Intellectual Capital, Vol. 8(2), 256-271.

Yu, K Y., Tai ng, H., Wong, W K., Chu, S. K W., and Chan, K H. (2010). An empirical study of the impact of intellectual capital performance on business performance. The 7th International Conference on IC, Knowledge Management \& Organizational Learning, The Hongkong Polytechnic University, Honh Kong. 